\title{
Regional pulmonary blood flow after mitral valve surgery
}

\author{
Bohuslav Král, Iva Křivková, Jiři Endrys, Jaroslav Procházka, Jiři Kubiček, Ivan Jurin, Zdeněk \\ Bělobrádek, Ivan Kosmák, and Jiří Kvasnička \\ From the 2nd Department of Medicine, the Department of Surgery, the Department of Radiology, and the Ist \\ Department of Medicine of the Faculty of Medicine, Charles University, Hradec Králové, Czechoslovakia
}

The authors investigated the index of pulmonary blood flow distribution between the upper and lower parts of the lungs in three groups of patients with acquired valvular heart disease before, and 3 and 12 months after surgical correction for mitral and aortic valve disease.

Three and 12 months after mitral valvotomy, there was a statistically significant decrease in the perfusion of the upper parts of the lungs. Three months after prosthetic mitral valve replacement, these changes were even more prominent. Three months after prosthetic aortic valve replacement, there were no changes in the index of distribution of pulmonary blood flow.

This method of measurement of the distribution of pulmonary blood flow is of value in the assessment of the results of mitral valve surgery.

Surgical correction of acquired mitral valve disease has been practised for more than 20 years. The assessment of the results of surgical treatment is based mainly on evaluation of symptoms and clinical, radiological, and electrocardiographic data (Ellis et al., 1965; Keith and Fowler, I972; Rees, Holswade, and Lillehei, 1972; Salzmann et al., 1972; Selzer and Cohn, 1972). Haemodynamic investigation cannot be undertaken in every patient after operation, for various reasons, e.g. patient's refusal, risks of the procedure, etc.

A good correlation between mean left atrial, and pulmonary arterial pressure, and the degree of redistribution of pulmonary blood flow to the upper parts of the lungs in patients with postcapillary pulmonary hypertension has often been found (Bell et al., I97I ; Dawson, Kaneko, and McGregor, 1965; Dollery and West, 1960; Friedman and Braunwald, 1966; Hughes et al., 1969; Jebavý et al., 1970; Sester, 197 ; Steiner and Quinn, 1968). We have confirmed that the radioisotope technique for the measurement of the distribution of pulmonary blood flow is useful as an indirect assessment of the mean left atrial pressure in patients with mitral valve disease (Endrys, Král, and Dvořák, 1968).

\section{Patients and methods}

We investigated 21 patients with predominant mitral Received 22 March 1973. stenosis, in whom mitral valvotomy was performed; to patients had mitral stenosis and regurgitation, and a prosthetic mitral valve replacement was done. For comparison, we studied 6 patients with aortic valve disease, in whom the aortic valve was replaced by a prosthesis. In all but 4 patients, the left atrial mean pressure and other haemodynamic parameters were measured before operation.

The index of pulmonary blood flow distribution between the upper and lower parts of the lungs was measured by ${ }^{133} \mathrm{Xe}$ method of Oppelt et al. (1966). Two scintillation counters were positioned behind the chest of the seated subject. The apical counter was placed at the level of the clavicle on the left side, and the basal counter at the level of the fifth anterior intercostal space in the midscapular line on the right side. Distribution of perfusion was studied by injecting $0.5-1.0 \mathrm{mCi}{ }^{133} \mathrm{Xe}$ in saline intravenously while the patient held his breath in full inspiration (Q). After equilibration of xenon in the lung spirometer system by rebreathing, the breathholding manoeuvre was repeated to determine the regional lung volume $(\mathrm{V})$. The levels of activity recorded during each breath-holding period were measured in counts per minute. The index of pulmonary blood flow distribution (IDPBF) was then calculated according to the formula: $\mathrm{IDPBF}=\frac{\dot{\mathrm{Q}} / \mathrm{V} \text { apical. }}{\dot{\mathrm{Q}} / \mathrm{V} \text { basal }}$ In our control subjects the value of this index was $0.25-0.60$.

Measurements of the distribution index were made before operation, and again at 3 months and 12 months, and in 5 patients 4 to 5 years, after operation.

The characteristics of patients investigated in this 
TABLE I Group I, mitral valvotomy

\begin{tabular}{|c|c|c|c|c|c|c|c|c|c|c|c|c|}
\hline $\begin{array}{l}\text { Case } \\
\text { No. }\end{array}$ & Sex & Age & Diagnosis & $\begin{array}{l}\text { Functional } \\
\text { class }\end{array}$ & $\begin{array}{l}\text { Left atrial } \\
\text { mean pressure } \\
(\mathrm{mmHg})\end{array}$ & $I_{1}$ & $I_{2}$ & $I_{3}$ & $I_{4}$ & $\Delta I_{1}-I_{2}$ & $\Delta I_{1}-I_{3}$ & $\Delta I_{1}-I_{4}$ \\
\hline $\mathbf{I}$ & $\mathrm{F}$ & 35 & Mitral stenosis & 3 & $22 \cdot 0$ & $2 \cdot 68$ & $I \cdot 4 I$ & $1 \cdot 25$ & 0.86 & $+\mathrm{I} \cdot 27$ & $+I \cdot 43$ & $+I \cdot 82$ \\
\hline 2 & $\mathrm{~F}$ & 40 & y & 3 & $33 \cdot 0$ & $1 \cdot 62$ & - & 0.83 & - & - & $\begin{array}{l}1.43 \\
+0.79\end{array}$ & - \\
\hline 3 & $\mathrm{~F}$ & 45 & $\begin{array}{l}\text { Mitral stenosis } \\
\text { and } \\
\text { regurgitation }\end{array}$ & 4 & $24 \cdot 0$ & $1 \cdot 32$ & $1 \cdot 42$ & $I \cdot 12$ & 0.85 & -0.10 & +0.20 & +0.47 \\
\hline 4 & $\mathbf{F}$ & 35 & \multirow[b]{2}{*}{$\begin{array}{l}\text { Mitral stenosis } \\
\text { Mitral stenosis } \\
\text { and } \\
\text { regurgitation, } \\
\text { tricuspid } \\
\text { stenosis }\end{array}$} & 3 & - & $I \cdot 4 I$ & $1 \cdot 02$ & 0.79 & - & +0.39 & +0.62 & - \\
\hline 5 & $\mathrm{~F}$ & 45 & & 4 & $14 \cdot 0$ & $\mathrm{I} \cdot 04$ & - & $1 \cdot 22$ & - & - & -0.18 & - \\
\hline 6 & $\mathbf{M}$ & 30 & Mitral stenosis & 3 & $21 \cdot 0$ & $I \cdot I 4$ & 0.88 & 0.68 & - & +0.26 & +0.46 & - \\
\hline 7 & $\mathbf{M}$ & 40 & " & 3 & 19.0 & $I \cdot 12$ & 0.87 & 0.75 & - & +0.25 & +0.37 & - \\
\hline 8 & $\mathrm{~F}$ & 35 & " & 3 & $24 \cdot 0$ & 0.92 & 0.90 & - & - & +0.02 & - & - \\
\hline 9 & F & 30 & " & 3 & 19.0 & $2 \cdot 02$ & $I \cdot 20$ & $I \cdot 20$ & - & +0.82 & +0.82 & - \\
\hline I0 & $\mathrm{F}$ & 32 & " & 2 & 8.5 & 0.69 & 0.79 & 0.73 & 0.91 & -0.10 & -0.04 & -0.22 \\
\hline II & F & 39 & 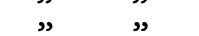 & 3 & $26 \cdot 0$ & I.94 & - & $1 \cdot 22$ & - & - & +0.72 & - \\
\hline 12 & $\mathrm{~F}$ & 38 & 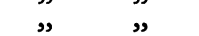 & 3 & 19.0 & I.OI & - & $1 \cdot 13$ & - & - & -0.12 & - \\
\hline 13 & $\mathbf{M}$ & 36 & " & 3 & $20 \cdot 0$ & $1 \cdot 68$ & $I \cdot 15$ & 0.86 & 0.61 & +0.53 & +0.82 & +1.07 \\
\hline 14 & $\mathrm{~F}$ & 34 & " & 3 & $34 \cdot 0$ & $I \cdot 86$ & 0.82 & - & 0.49 & $+\mathrm{I} .04$ & - & $+\mathrm{r} \cdot 37$ \\
\hline 15 & $\mathbf{F}$ & 28 & " & 3 & $17 \cdot 0$ & 0.98 & 0.67 & - & - & +0.31 & - & - \\
\hline 16 & $\mathrm{~F}$ & 36 & " & 3 & - & $\mathrm{I} \cdot 86$ & - & $1 \cdot \infty$ & - & - & +0.86 & - \\
\hline 17 & $\mathrm{~F}$ & 38 & " & 4 & $23 \cdot 0$ & $2 \cdot 32$ & - & 0.94 & - & - & $+1 \cdot 38$ & - \\
\hline 18 & $\mathbf{M}$ & 40 & \multirow[b]{2}{*}{$\begin{array}{l}\text { Mitral stenosis, } \\
\text { tricuspid } \\
\text { stenosis and } \\
\text { regurgitation }\end{array}$} & 3 & 25.0 & $1 \cdot \infty$ & 0.73 & - & - & +0.27 & - & - \\
\hline 19 & $\mathrm{~F}$ & 39 & & 4 & $38 \cdot 0$ & $1 \cdot 53$ & $1 \cdot 30$ & - & - & +0.23 & - & - \\
\hline 20 & $\mathbf{M}$ & 38 & \multirow{2}{*}{$\begin{array}{l}\text { Mitral stenosis } \\
\text { Mitral stenosis, } \\
\text { mitral } \\
\text { regurgitation }\end{array}$} & 3 & $20 \cdot 0$ & 0.86 & 0.63 & - & - & +0.23 & - & - \\
\hline 21 & F & $2 I$ & & 3 & - & $1 \cdot 25$ & 0.80 & - & - & +0.45 & - & - \\
\hline
\end{tabular}

Footnotes: $I$ = index of distribution of pulmonary blood flow between upper and lower lung field.

$I_{1}=$ before operation.

$I_{2}=3$ months after operation.

$\mathrm{I}_{3}=\mathrm{I}$ year after operation.

$I_{4}=4$ to 5 years after operation.

study and the results are presented in Tables 1,2 , and 3. The statistical evaluation of the data was made with the aid of the t-test and correlation coefficients.

\section{Results}

Fig. I shows a correlation between the mean left atrial pressure and the index of distribution of pulmonary blood flow in patients of all 3 groups investigated. In another group of patients with mitral valve disease, investigated previously, we found a better correlation between these two parameters $(r=0.784)$ (Endrys et al., 1968). There is progressively less diversion of pulmonary blood flow to the upper part of the lung 3 and 12 months after operation, the difference being more pronounced in patients after mitral valve replacement (Fig. 2 and 3 , Tables 4 and 5). The distribution of pulmonary blood flow in patients with aortic heart valve disease was only slightly abnormal before operation and did not change significantly after operation (Fig. 3). The decrease in the index of distribution of pulmonary blood flow after mitral valve surgery was greater, the more abnormal the index before operation (Fig. 4).

\section{Discussion}

Many reports have shown the tendency of pulmonary artery and left atrial pressure and of pulmonary vascular resistance to return to normal values after mitral valve operations (Braunwald et al., 1965; Carey and Plested, 1972; Dalen et al., 1967; Donald et al., 1957; Graham et al., 1971; Heinz et al., 1972; Hoffmeister et al., 1972; Lee et al., 1971; Moccetti et al., 1970, 1972; Morrow et al., 1967; Mullin et al., 1972; Reeve et al., 1966; Semler, Shepherd, and Wood, I959). These 
1198 Král et al.

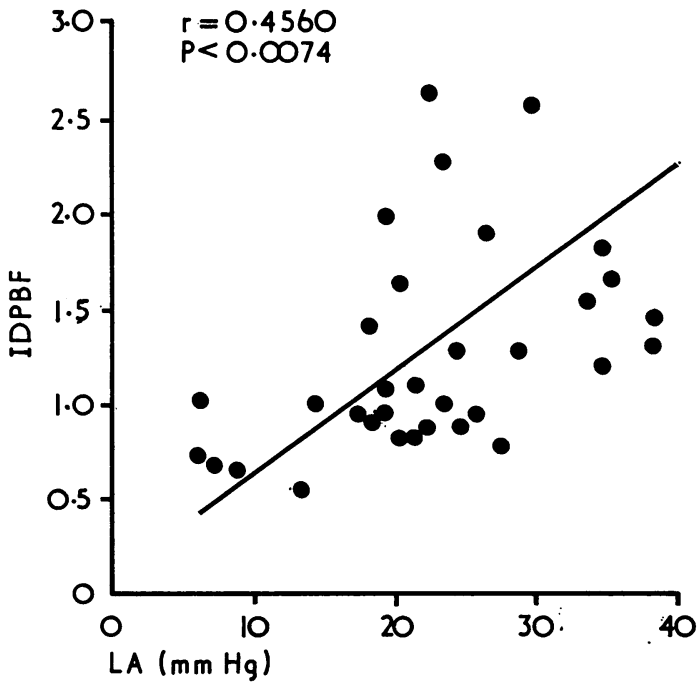

FIG. I Mean left atrial pressure $(L A)$ in relation to the index of distribution of pulmonary blood flow (IDPBF) in patients with acquired valvular heart disease. The correlation coefficient $(r=0.456)$ is statistically significant $(P<0.01)$.

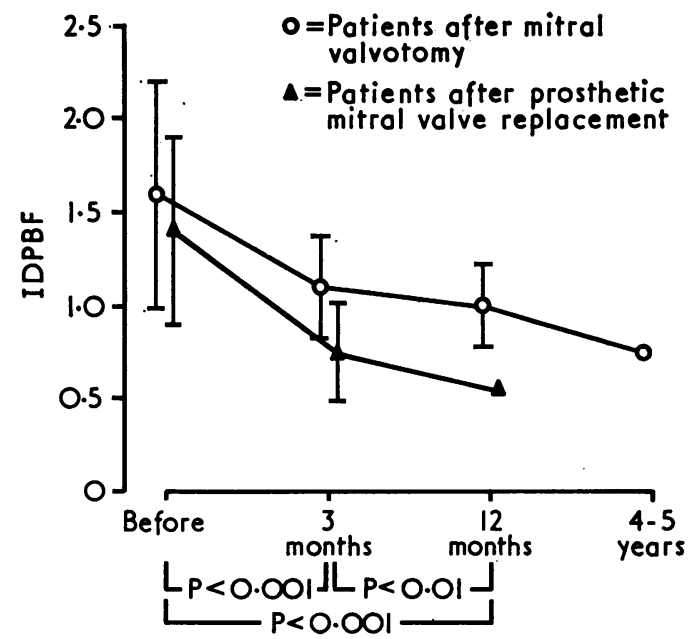

FIG. 2 The index of distribution of pulmonary blood flow (IDPBF) before, 3, and 12 months, and 4 to 5 years after mitral valvotomy (open circles) and after prosthetic mitral valve replacement (squares). The differences found 3 and $I 2$ months after mitral valvotomy and after mitral valve replacement are statistically highly significant.

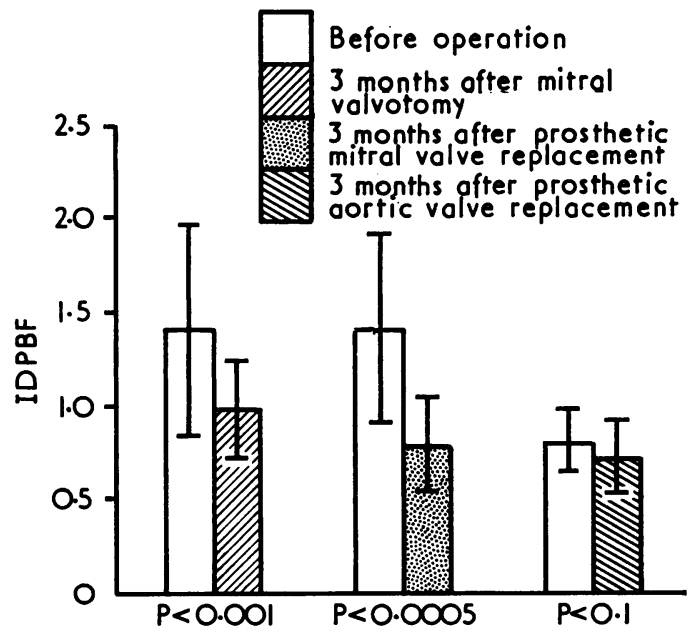

FIG. 3 The index of distribution of pulmonary blood flow (IDPBF) before and 3 months after mitral valvotomy, prosthetic mitral valve replacement, and prosthetic aortic valve replacement. The most striking decrease in the index is seen after mitral valve replacement; this was less in mitral valvotomy patients; there was no difference after aortic valve replacement.

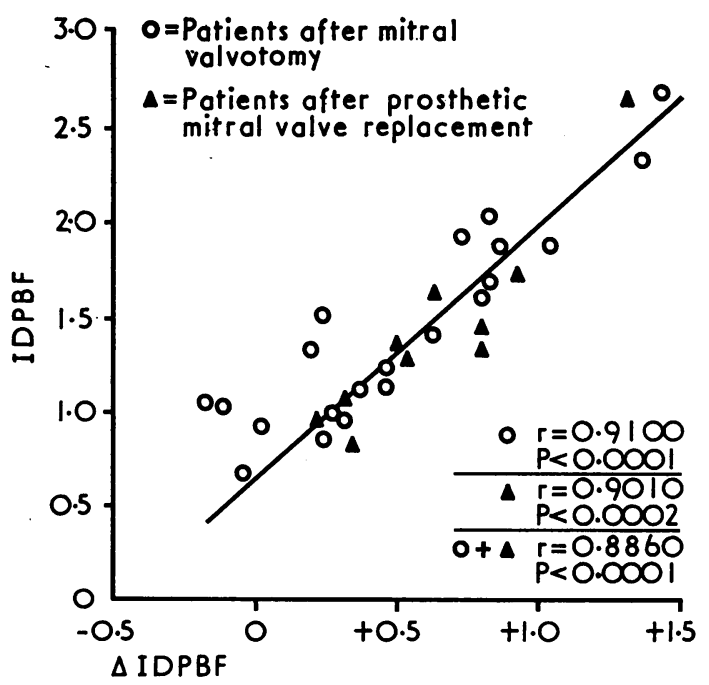

FIG. 4 The preoperative value of the index of distribution of pulmonary blood flow (IDPBF) is related to the difference between preoperative and postoperative values $(\triangle I D P B F)$. A highly significant correlation index $(r=0.886)$ can be seen in both groups of patients investigated in this study. 
TABLE 2 Group 2, prosthetic mitral valve replacement

\begin{tabular}{|c|c|c|c|c|c|c|c|c|c|c|c|c|}
\hline $\begin{array}{l}\text { Case } \\
\text { No. }\end{array}$ & Sex & Age & Diagnosis & $\begin{array}{l}\text { Functional } \\
\text { class }\end{array}$ & $\begin{array}{l}\text { Left atrial } \\
\text { mean pressure }\end{array}$ & $I_{1}$ & $I_{2}$ & $I_{3}$ & $I_{4}$ & $\Delta_{1} I-I_{2}$ & $\Delta I_{1}-I_{3}$ & $\Delta I_{1}-I_{4}$ \\
\hline 22 & $\mathrm{~F}$ & 26 & Mitral stenosis & 3 & $29 \cdot 0$ & $2 \cdot 62$ & $I \cdot 3 I$ & - & - & $+I \cdot 3 I$ & - & - \\
\hline 23 & $\mathrm{~F}$ & 36 & $\begin{array}{l}\text { Mitral stenosis, } \\
\text { tricuspid } \\
\text { stenosis, tri- } \\
\text { cuspid } \\
\text { regurgitation, } \\
\text { aortic stenosis }\end{array}$ & 4 & $23 \cdot 0$ & $1 \cdot 08$ & 0.77 & 0.71 & - & +0.31 & +0.37 & 一 \\
\hline 24 & $M$ & 34 & $\begin{array}{l}\text { Mitral stenosis, } \\
\text { mitral } \\
\text { regurgitation }\end{array}$ & 4 & $38 \cdot 0$ & $1 \cdot 36$ & 0.87 & 0.73 & - & +0.49 & +0.63 & - \\
\hline 25 & $\mathbf{M}$ & 37 & $\begin{array}{l}\text { Mitral stenosis, } \\
\text { mitral } \\
\text { regurgitation }\end{array}$ & 3 & $28 \cdot 0$ & $1 \cdot 29$ & 0.49 & 0.23 & - & +0.80 & $+1 \cdot 06$ & 一 \\
\hline 26 & $\mathrm{~F}$ & 4I & $\begin{array}{l}\text { Mitral stenosis, } \\
\text { mitral } \\
\text { regurgitation }\end{array}$ & 3 & $27 \cdot 0$ & 0.82 & 0.49 & 0.60 & 一 & +0.33 & +0.22 & - \\
\hline 27 & $\mathbf{M}$ & 38 & $\begin{array}{l}\text { Mitral stenosis, } \\
\text { mitral } \\
\text { regurgitation }\end{array}$ & 3 & $18 \cdot 0$ & $I \cdot 43$ & 0.52 & - & - & +0.91 & - & - \\
\hline 28 & $\mathbf{M}$ & 36 & $\begin{array}{l}\text { Mitral stenosis, } \\
\text { mitral } \\
\text { regurgitation }\end{array}$ & 4 & $35 \cdot 0$ & $I \cdot 72$ & 0.80 & 一 & - & +0.92 & 一 & - \\
\hline 29 & $M$ & 37 & $\begin{array}{l}\text { Mitral stenosis, } \\
\text { mitral } \\
\text { regurgitation }\end{array}$ & 3 & $34 \cdot 0$ & $I \cdot 26$ & 0.72 & - & - & +0.54 & - & - \\
\hline 30 & $\mathbf{F}$ & 33 & $\begin{array}{l}\text { Mitral stenosis, } \\
\text { tricuspid } \\
\text { stenosis, } \\
\text { aortic stenosis }\end{array}$ & 4 & $18 \cdot 0$ & 0.95 & 0.72 & - & - & +0.23 & - & - \\
\hline $3 I$ & $\mathbf{F}$ & 39 & $\begin{array}{l}\text { Mitral stenosis, } \\
\text { mitral } \\
\text { regurgitation }\end{array}$ & 3 & - & $I \cdot 62$ & 0.99 & - & - & +0.63 & - & - \\
\hline
\end{tabular}

Note: See footnote to Table I for explanation of column headings.

TABLE 3 Group 3, prosthetic aortic valve replacement

\begin{tabular}{|c|c|c|c|c|c|c|c|c|c|c|c|c|}
\hline $\begin{array}{l}\text { Case } \\
\text { No. }\end{array}$ & Sex & Age & Diagnosis & $\begin{array}{l}\text { Functional } \\
\text { class }\end{array}$ & $\begin{array}{l}\text { Left atrial } \\
\text { mean pressure }\end{array}$ & $I_{1}$ & $I_{2}$ & $I_{3}$ & $I_{4}$ & $\Delta I_{1}-I_{2}$ & $\Delta I_{1}-I_{3}$ & $\Delta I_{1}-I_{4}$ \\
\hline 32 & $M$ & 38 & $\begin{array}{l}\text { Aortic stenosis, } \\
\text { aortic } \\
\text { regurgitation }\end{array}$ & 2 & $6 \cdot 0$ & 0.76 & 0.42 & 0.56 & - & +0.34 & +0.20 & - \\
\hline 33 & $\mathbf{M}$ & 36 & $\begin{array}{l}\text { Aortic stenosis, } \\
\text { aortic } \\
\text { regurgitation }\end{array}$ & 4 & $22 \cdot 0$ & 0.89 & 0.92 & 0.64 & - & -0.03 & +0.25 & \\
\hline 34 & $\mathbf{F}$ & 33 & $\begin{array}{l}\text { Mitral stenosis, } \\
\text { aortic stenosis, } \\
\text { aortic } \\
\text { regurgitation }\end{array}$ & 3 & $7 \cdot 0$ & $0.7 \mathrm{I}$ & 0.55 & - & - & +0.16 & - & - \\
\hline 35 & $\mathbf{M}$ & $4 I$ & $\begin{array}{l}\text { Aortic } \\
\text { regurgitation }\end{array}$ & 3 & $6 \cdot 0$ & $I \cdot 07$ & 0.87 & - & - & +0.20 & - & - \\
\hline 36 & $\mathbf{M}$ & 33 & $\begin{array}{l}\text { Aortic stenosis, } \\
\text { aortic } \\
\text { regurgitation }\end{array}$ & 3 & $21 \cdot 0$ & 0.87 & 0.89 & - & - & -0.02 & - & - \\
\hline 37 & $\mathrm{~F}$ & 28 & $\begin{array}{l}\text { Aortic stenosis, } \\
\text { aortic regurgita }\end{array}$ & $\underset{2}{2}$ & $13 \cdot 0$ & 0.57 & 0.63 & - & - & -0.06 & - & - \\
\hline
\end{tabular}

Note: See footnote to Table $\mathrm{I}$ for explanation of column headings. 
TABLE 4 Statistical evaluation of changes in distribution of pulmonary blood flow 3 months, 12 months, and 4 to 5 years after mitral valvotomy

\begin{tabular}{|c|c|c|c|c|c|c|c|c|}
\hline \multicolumn{3}{|c|}{ Index $(I D P B F)$} & \multicolumn{3}{|c|}{ Index $(I D P B F)$} & \multicolumn{3}{|c|}{ Index (IDPBF) } \\
\hline No. & Before & $\begin{array}{l}3 \text { months after } \\
\text { operation }\end{array}$ & No. & Before & $\begin{array}{l}12 \text { months after } \\
\text { operation }\end{array}$ & No. & Before & $\begin{array}{l}4 \text { to } 5 \text { years after } \\
\text { operation }\end{array}$ \\
\hline \multirow[t]{2}{*}{16} & $1.423 \pm 0.56$ & $0.970 \pm 0.25$ & 13 & $1 \cdot 511 \pm 0.48$ & $0.980 \pm 0.22$ & 5 & $1.621 \pm 0.68$ & $0.745 \pm 0.2 I$ \\
\hline & $\mathbf{P}<0.001$ & & & $\mathbf{P}<0.001$ & & & - & \\
\hline
\end{tabular}

TABLE 5 Statistical evaluation of changes in distribution of pulmonary blood flow 3 and 12 months after prosthetic mitral valve replacement

\begin{tabular}{llllll}
\hline \multicolumn{3}{l}{ Index $(I D P B F)$} & \multicolumn{3}{c}{ Index $(I D P B F)$} \\
\hline No. & Before & 3 months after operation & No. & Before & I2 months after operation \\
\hline I0 & I.415 \pm 0.50 & $0.768 \pm 0.25$ & 4 & $1 \cdot 140$ & 0.528 \\
\hline & $\mathrm{P}<0.0005$ & & - & \\
\hline
\end{tabular}

changes were greater and occurred earlier after mitral valve replacement than after mitral valvotomy. Our results are in good agreement with these haemodynamic obervations.

The greatest decrease in the index of distribution of pulmonary blood flow after operation was observed in patients with the greatest abnormality of distribution of pulmonary blood flow before operation, caused perhaps by severe vasoconstriction in the lower parts of the lungs, and its immediate release after successful surgery. In 4 patients examined 4 to 5 years after mitral valvotomy there was a further decrease in the index, indicating further return towards normal pulmonary blood flow distribution. This could be a functional reflection of the continuing regression of anatomical changes in the pulmonary vasculature after successful relief of mitral valve obstruction (Nicks and McGovern, 1968). This observation is consistent with the results of Ferguson and Varco (1955), who found experimentally that the regression of pathological pulmonary vascular changes was a slow process.

We have found good agreement between the changes in distribution of pulmonary blood flow and the clinical symptoms and signs in these patients. Cases 5 and 12 had mitral regurgitation after operation, and the diversion of pulmonary blood flow to the parts of the upper lungs remained unchanged. Case ro had systemic emboli before operation, but haemodynamically insignificant mitral stenosis. Four years after operation, there were signs of restenosis and the patient became breath- less. In this patient, the index of pulmonary blood flow distribution was only slightly raised before operation, and increased at 4 to 5 years. Cases 13 and 14 had almost normal distribution of pulmonary blood flow 5 years after mitral valvotomy, when they had no residual disability.

Despite the indirect character of this method in evaluating pulmonary haemodynamics, we have found the measurement of the index of pulmonary blood flow distribution to be useful in the evaluation of the results of mitral valve surgery (Endrys et al., 1972). This is in agreement with other authors (Cellerino, Andreone, and Gaetini, 1971; Krishnamurthy, Srinivasan, and Blahd, I971, 1972).

\section{References}

Bell, R. L., Alvarez, A., Johnson, P. C., and Stevens, P. A. (I971). Estimation of mean pulmonary artery pressure derived from Xenon lung studies (abstract). Fournal of Nuclear Medicine, 12, 415.

Braunwald, E., Braunwald, N. S., Ross, J., Jr., and Morrow, A. G. (1965). Effects of mitral-valve replacement on the pulmonary vascular dynamics of patients with pulmonary hypertension. New England fournal of Medicine, 273, 509.

Carey, J. S., and Plested, W. G. (I972). Immediate hemodynamic response to correction of cardiac valvular lesions. Annals of Thoracic Surgery, 13, $31 \mathrm{I}$.

Cellerino, A., Andreone, A., and Gaetini, A. (I97I). Blood distribution through the lungs before and after mitral commissurotomy: a quantitative assessment by ${ }^{131}$ I. fournal of Cardiovascular Surgery, 12, 66.

Dalen, J. E., Matloff, J. M., Evans, G. L., Hoppin, F. G., Jr., Bhardwaj, P., Harken, D. E., and Dexter, L. (1967). Early reduction of pulmonary vascular resistance after mitral- 
valve replacement. New England fournal of Medicine, 277, 387.

Dawson, A., Kaneko, K., and McGregor, M. (1965). Regional lung function in patients with mitral stenosis studied with xenon ${ }^{133}$ during air and oxygen breathing. Fournal of Clinical Investigation, 44, 999.

Dollery, C. T., and West, J. B. (1960). Regional uptake of radioactive oxygen, carbon monoxide and carbon dioxide in the lungs of patients with mitral stenosis. Circulation Research, 8, 765 .

Donald, K. W., Bishop, J. M., Wade, O. L., and Wormald, P. N. (1957). Cardiorespiratory function two years after mitral valvotomy. Clinical Science, 16, 325.

Ellis, F. H., Jr., Callahan, J. A., McGoon, D. C., and Kirklin, J. W. (I965). Results of open operation for acquired mitral-valve disease. New England fournal of Medicine, 272, 869.

Endrys, J., Král, B., and Dvořák, K. (1968). Measurement of regional pulmonary blood flow in evaluation of severity of mitral stenosis. Abstract of the 5th European Congress of Cardiology, Athens, p. 137.

Endrys, J., Král, B., Reinisch, E., and Procházka, J. (1972). Regionální plicní perfúze a ventilace před komisurolýzou mitrálni chlopně a po ni. Časopis Lékař̆ Českých, 111, 63.

Ferguson, D. J., and Varco, R. L. (1955). The relation of blood pressure and flow to the development and regression of experimentally induced pulmonary arteriosclerosis. Circulation Research, 3, 152.

Friedman, W. F., and Braunwald, E. (1966). Alterations in regional pulmonary blood flow in mitral valve disease studied by radioisotopic scanning. Circulation, 34, 363 .

Graham, A. F., Schroeder, J. S., Daily, P. O., and Harrison, D. C. (1971). Clinical and hemodynamic studies in patients with homograft mitral valve replacement. Circulation, 44, 334.

Heinz, N., Kalmar, P., Luckmann, E., Rodewald, G., and Rödiger, W. (1972). Morbidität nach Mitralklappenersatz. Thoraxchirurgie, 20, 347.

Hoffmeister, H. E., Brunner, L., Kalbow, K., Sinha, K., and Koncz, J. (1972). Offene oder geschlossene Operation der Mitralstenose höheren Schweregrades? Thoraxchirurgie, 20, 38.

Hughes, J. M. B., Glazier, J. B., Rosenzwieg, D. Y., and West, J. B. (1969). Factors determining the distribution of pulmonary blood flow in patients with raised pulmonary venous pressure. Clinical Science, 37, 847.

Jebavý, P., Runczik, I., Oppelt, A., Tilsch, J., Staněk, V., and Widimský, J. (1970). Regional pulmonary function in patients with mitral stenosis in relation to haemodynamic data. British Heart fournal, 32, 330.

Keith, T. A., and Fowler, N. O. (1972). Closed mitral commissurotomy. Complications and their effect on survival. Chest, 6r, 24.

Krishnamurthy, G. T., Srinivasan, N. V., and Blahd, W. H. (197I). Postoperative followup of cardiac surgery patients by a scintillation camera technique (abstract). Fournal of Nuclear Medicine, 12, 445.

Krishnamurthy, G. T., Srinivasan, N. V., and Blahd, W. H.
(1972). Pulmonary hypertension in acquired valvular cardiac disease: evaluation by a scintillation camera technique. fournal of Nuclear Medicine, 13, 604.

Lee, S. J. K., Zaragoza, A. J., Callaghan, J. C., Rossall, R. E., and Fraser, R. S. (197I). Hemodynamic changes following mitral valve replacement with the Starr-Edwards and Cutter-Smeloff prostheses. Fournal of Thoracic and Cardiovascular Surgery, 61, 688.

Moccetti, T., Albert, H., Bühlmann, A., Senning, A., and Lichtlen, P. (1972). Haemodynamics after mitral valvotomy. Reasons for unsatisfactory clinical results. British Heart fournal, 34, 493.

Moccetti, T., Albert, H., Lichtlen, P., and Senning, A. (1970). Hämodynamische Untersuchungen nach Mitralkommissurotomie. Analyse an Hand von 54 Patienten. Schweizerische medizinische Wochenschrift, 100, 2189.

Morrow, A. G., Oldham, H. N., Elkins, R. C., and Braunwald, E. (1967). Prosthetic replacement of the mitral valve: preoperative and postoperative clinical and hemodynamic assessments in 100 patients. Circulation, 35, 962.

Mullin, E. M., Jr., Glancy, D. L., Higgs, L. M., Epstein, S. E., and Morrow, A. G. (1972). Current results of operation for mitral stenosis. Circulation, 46, 298.

Nicks, R., and McGovern, V. J. (1968). Influence of pulmonary vascular disease and fibrosis on prognosis following closed valvotomy. Thorax, 23, I 53 .

Oppelt, A., Widimský, J., Staněk, V., Blaha, V., Runczik, I., and Vavrejn, B. (1966). Regional pulmonary function in normals and in disease studied by intravenously injected

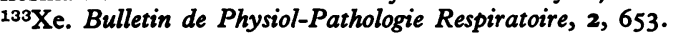

Rees, J. R., Holswade, G. R., and Lillehei, C. W. (1972). Patients status five or more years after mitral valve replacement. Annals of Thoracic Surgery, 14, 30.

Reeve, R., Selzer, A., Popper, R. W., Leeds, R. F., and Gerbode, F. (I966): Reversibility of pulmonary hypertension following cardiac surgery. Circulation, 33, Suppl. I, 107.

Salzmann, C., Sutton, G. C., Chatterjee, K., Kerr, I. H., and Miller, G. A. H. (1972). Assessment of homograft replacement of mitral valve by chest radiographs. British Heart fournal, 34, 121.

Selzer, A., and Cohn, K. E., (1972). Natural history of mitral stenosis. Circulation, 45, 878.

Semler, H. J., Shepherd, J. T., and Wood, E. H. (1959). The role of vessel tone in maintaining pulmonary vascular resistance in patients with mitral stenosis. Circulation, 19, 386.

Sester, L. (1971). Quantification of regional pulmonary blood flow with a scintillation camera and data processor (abstract). Fournal of Nuclear Medicine, 12, 481.

Steiner, S. H., and Quinn, J. M. (1968). Cardiovascular hemodynamics: determination from the distribution of pulmonary blood flow in seated patients. Fournal of the American Medical Association, 203, 130.

Requests for reprints to Dr. Bohuslav Král, 2nd Department of Medicine, Faculty of Medicine, Hradec Králové Czechoslovakia. 